\title{
Networked interactive solar panels over the roof photovoltaic system (PVS) and its cost analysis at Tashkent state technical University
}

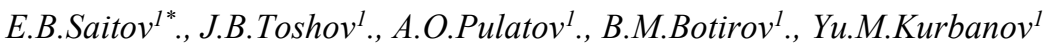 \\ ${ }^{1}$ Tashkent State Technical University, Uzbekistan, 100095, Tashkent, University St., 2.
}

\begin{abstract}
There is great potential for generating solar energy using unused space on roofs and vacant lots around buildings. Small amounts of energy generated by each individual household, industrial building, commercial building, or any other type of building can be used to partially meet the needs of the building's residents, and the surplus, if any, can be fed to the grid. To use the existing roof space of buildings, SPV systems on the roof of buildings can be installed to replace DG generators installed to provide the minimum load required to operate during load shedding. TSTU has a large unused roof area from both residential and office buildings. Therefore, it has a huge potential for generating solar energy by installing a grid-connected Solar system on the roof. We can reduce a large amount of bills by implementing a solar power plant. The government has also launched various solar energy incentive schemes, this article provides a brief overview of rooftop photovoltaic and small-scale solar generation systems, and discusses various government schemes. Since TSTU has a large scope for this scheme, so the calculation of the design capacity was made for the technological College and one residential building. A method has been developed for calculating the capacity of Autonomous solar power plants and its elements, which allows us to take into account changes in the load during the day and thereby accurately determine the required capacity of the battery and eliminate unjustified overestimation of the power of power plant elements and increase the cost of the Autonomous solar power plant itself.
\end{abstract}

\section{Introduction}

Electricity generation from solar-cell power plants is used almost all over the world today, and the use of solar panels is constantly growing. This is facilitated by many factors, the main of which are the use of alternative (renewable) energy sources, which have recently become increasingly relevant and the complete absence of any moving parts, so that their service life is practically unlimited [1-4]. Solar cell power plants are constantly being improved. Today, they can be used as additional sources of power supply, working together with others or completely autonomous.

Solar power plant not connected with the industrial grid, i.e. stand-alone solar power station (SPS), designed to supply a small country house, country houses, sports fields, knots ties, etc., i.e. consumers remote from electricity networks, the supply of electricity which usually entails high financial and labor costs.

There are PVS with a stable and unstabilized output voltage [5-8]. the functional circuits of Autonomous solar power plants consist of solar panels, the necessary power - to convert sunlight into electricity; pulse DC voltage converters - to bring the floating voltage of solar modules and batteries to a stable voltage and charge the batteries, which can be combined into a charge-discharge controller for batteries; batteries - for accumulating and storing electricity; Autonomous voltage inverter - for converting DC to AC $220 \mathrm{~V}$ and powering household electrical appliances.

Solar photovoltaic systems for generating electricity have been deployed in various parts of the country for electrification where grid connections are either impracticable or economically inefficient, and in some cases in combination with diesel generating stations in isolated locations and communication transmitters in remote locations. Due to the downward trend in the cost of solar energy and the recognition of the need to develop solar energy, solar energy projects have recently been implemented. Much of the country's large solar energy potential can be developed by promoting gridlinked solar photovoltaic power systems of various sizes according to needs and availability, combined with ensuring adequate returns on investment. Since the University of TSTU has a large scope for this scheme, so the calculation of the design capacity was made for the technological College and one residential building [912].

For the design of Autonomous solar power plants, it is necessary to determine the rated power of solar modules, their number, battery capacity, power of the inverter and the charge-discharge controller. The

\footnotetext{
* Corresponding author: elyor.saitov@mail.uz
} 
necessary data for calculating the capacity of solar power plant are: location; the existing liner (if any); total floor area; number of rooms; used equipment; the availability of heating and hot water supply; total maximum power of all appliances; the approximate time of each of the electrical load.

These issues are not fully covered in the available literature, so the development of methods for calculating the capacity of Autonomous solar power plants and its elements is an urgent task.

The purpose of this study is to develop a method for calculating the capacity of Autonomous solar power plants, which is divided into several main stages for ease of presentation. Let's take a closer look at the calculation method for the proposed stages.

\section{Main Body}

\subsection{Theoretical analysis}

Description of solar energy conversion: Solar energy can be converted in two ways (1) by solar thermal generation (2) by solar solar cell. Now solar PV cells can be installed in stand-alone mode and in connected mode to the network.

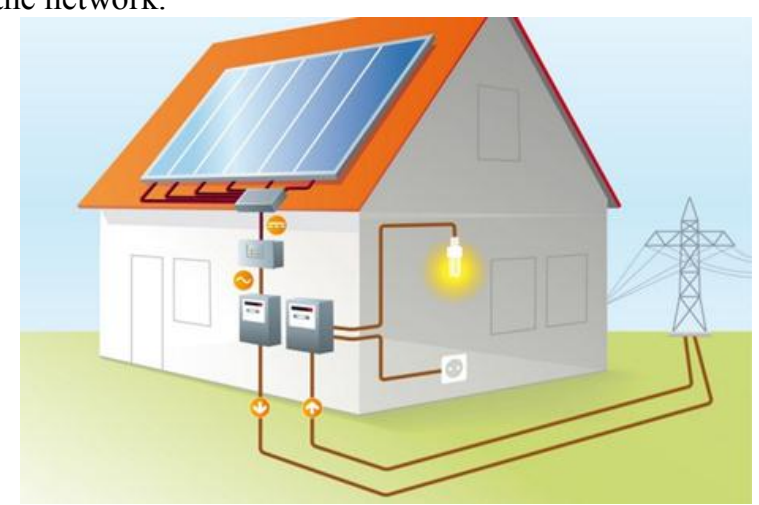

a)

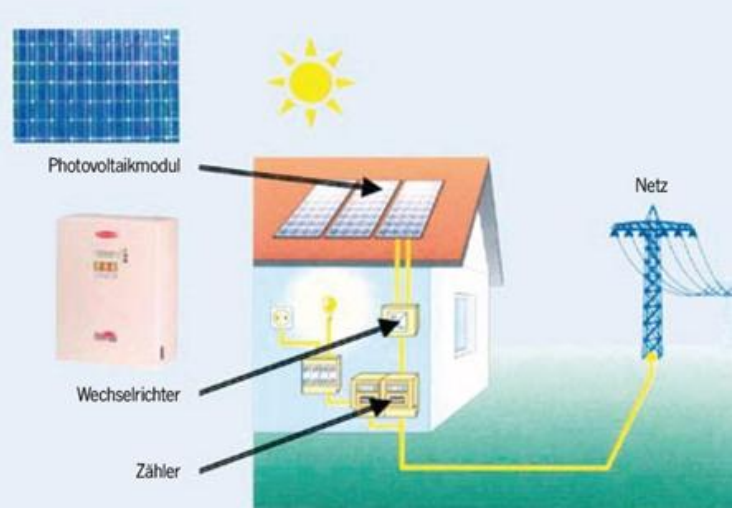

b)

a) Autonomous solar systems can be cheaper than extending power lines in some remote areas where the grid is not available.

b) if we use an isolated system where there is a network, the reliability of power supply increases.

Fig. 1. The advantages of stand-alone solar systems.
Autonomous or isolated solar systems. An off-grid solar system (off-the-grid, Autonomous) is very useful especially for those places where the grid is not available. To provide constant access to electricity, Autonomous solar systems require battery packs and a backup generator (if you live off-grid). In addition, the battery usually needs to be replaced after 5 years. Batteries are complex, expensive, and reduce the overall efficiency of the system.

Calculation of the PES output power. When designing an Autonomous solar power plant, you first need to make a list of all electricity consumers, find out their power consumption, voltage and enter it in the list (table 1). AC voltage consumers (№1 - № 4, table 1) are connected to the main power bus of the PVS through individual Autonomous voltage inverters, and DC voltage consumers H1, H2 (№7 and № 8, table 1). 1) with voltage values that differ from the nominal value of the main bus voltage - via DC pulse converters of both increasing and decreasing types [13-16]. The consumer (№. 5, table 1) is connected "directly" to the main power bus, and the consumer (№. 6, table 1) is connected to an additional power bus, i.e. to a separate battery of the PVS. For the main power bus, the bus is taken, to which the PVS battery is connected at night, either directly or through a step-up PPI. In our example, the main power bus is a bus with a voltage $=24 \mathrm{~V}$, corresponding to the voltage of the PVS battery.

If there are loads with different types and values of supply voltages in the list of consumers, it is necessary to recalculate their power to the main power bus of the PES. Then the power of individual loads on the main power bus is recalculated using the formula:

$$
P_{\mathrm{oc}, i}=P_{H, i} / \eta_{i}
$$

Where, $P_{H, i}-$ power of the i-th consumer; $P_{\mathrm{oc}, i^{-}}$ power of the $\mathrm{i}$-th consumer, converted to the main bus of the PVS; $\eta_{i}-$ the efficiency of the i-th Autonomous voltage inverter or the $\mathrm{i}$-th pulse $\mathrm{DC}$ voltage Converter for consumers, respectively, AC and DC currents (in table 1 , the efficiency of the AVI and ICCV is assumed to be equal to 0.8 ).

If the DC consumer is connected to the main power bus "directly" or is powered from a separate battery with a voltage less than the voltage of the PVS battery (No. 6, table 1), then in the conversion formula (1), the efficiency is assumed to be equal to one [17-20].

Then you need to estimate how much time during the day these or other electrical appliances are used, and by multiplying the power of the device by the time of its operation, determine the daily need for electricity, write this data in the corresponding columns of the table. This is how the table of total energy consumption per day is compiled. Table of total energy consumption per day table 1. A solar power plant can power many electrical appliances, provided that their energy consumption does not exceed the amount of electricity produced by the PVS. The list of electricity consumers contains loads that work either constantly or intermittently (rarely, very rarely). In turn, loads that operate intermittently are divided into loads that operate with a fixed and floating operating interval (for example, refrigerator - №. 3, table 
1). Ignoring these factors can lead to an unjustified overestimation of output power and increase the cost of an Autonomous solar power plant. Therefore, it is necessary to correctly determine the output power of an Autonomous solar power plant [21-23].

Table 1. Table of total energy consumption per day [24].

\begin{tabular}{|c|c|c|c|c|c|}
\hline $\begin{array}{l}\text { № } \\
\text { s/n }\end{array}$ & Load & $\begin{array}{l}\text { Voltage, } \\
\text { Power }\end{array}$ & $\begin{array}{c}\text { Power } \\
\text { on } \\
\text { main } \\
\text { bus, W }\end{array}$ & $\begin{array}{l}\text { Oper } \\
\text { ating } \\
\text { time, } \\
\text { h/day }\end{array}$ & $\mid \begin{array}{c}\text { Energy } \\
\text { consum } \\
\text { ption, } \\
\mathbf{W} \times \mathbf{h} / \mathbf{d a} \\
\mathbf{y}\end{array}$ \\
\hline 1. & $\begin{array}{c}\text { Electric } \\
\text { kettle, AVI }\end{array}$ & $\begin{array}{c}\sim 220 \mathrm{~V}, \\
1000 \mathrm{~W}\end{array}$ & 1250 & 0,25 & 312,5 \\
\hline 2. & $\begin{array}{c}\text { Microwave } \\
\text { oven, AVI }\end{array}$ & $\begin{array}{c}\sim 220 \mathrm{~V}, \\
1200 \mathrm{~W}\end{array}$ & 1500 & 0,25 & 375 \\
\hline 3. & $\begin{array}{c}\text { Refrigerator, } \\
\text { AVI }\end{array}$ & $\begin{array}{c}\sim 220 \mathrm{~V}, \\
250 \mathrm{~W}\end{array}$ & 312,5 & 12 & 3750 \\
\hline 4. & $\begin{array}{c}\text { Television, } \\
\text { AVI }\end{array}$ & $\begin{array}{c}\sim 220 \mathrm{~V}, \\
150 \mathrm{~W}\end{array}$ & 187,5 & 4 & 750 \\
\hline 5. & $\begin{array}{l}\text { Lighting of } \\
\text { holl }\end{array}$ & $\begin{array}{l}=24 \mathrm{~V} \\
100 \mathrm{~W}\end{array}$ & 100 & 4 & 400 \\
\hline 6. & $\begin{array}{l}\text { Lighting of } \\
\text { dining room } \\
\text { and toilet }\end{array}$ & $\begin{array}{l}=12 \mathrm{~V} \\
50 \mathrm{~W}\end{array}$ & 50 & 5 & 250 \\
\hline 7. & $\begin{array}{c}\text { Consumer } \\
\text { H1, } \\
\text { ICCV }\end{array}$ & $\begin{array}{l}=48 \mathrm{~V} \\
120 \mathrm{~W}\end{array}$ & 150 & 5 & 750 \\
\hline 8. & $\begin{array}{c}\text { Consumer } \mathrm{H}_{2}, \\
\mathrm{ICCV}\end{array}$ & $\begin{array}{l}=12 \mathrm{~V}, \\
90 \mathrm{~W}\end{array}$ & 112,5 & 3 & 337,5 \\
\hline & Total & & 3662,5 & & 6925 \\
\hline
\end{tabular}

\subsection{Experimental part}

In this regard, the urgent problem is the problem of the use of renewable energy sources (RES), wind and solar energy etc. Moreover, when burning organic fuel, the atmosphere and the natural environment as a whole are polluted.

In Uzbekistan, since 1987, a Large Solar Furnace with a thermal capacity of $100 \mathrm{~kW}$ has been operated [25-28], and now, according to the press service of the
Ministry of investment and foreign trade of Uzbekistan, the leading international company Masdar (UAE) will build one of the largest wind farms in the world with a capacity of $500 \mathrm{MW}$ in Navoi region. This is the second major project implemented by this company in the Republic of Uzbekistan - in October last year, Masdar won a tender for the construction of a $100 \mathrm{MW}$ solar power plant in the Navoi region on the basis of a publicprivate partnership. The relevant agreements for the implementation of this project were signed in January 2020.

In order to measure solar and wind resources, modern automatic weather stations were built in six regions of Uzbekistan in 2013 [29-30]. in 2019, a meteorological mast with a height of $100 \mathrm{~m}$ was built in the Gallaaral and Forish districts of the Jizzakh region to study potential wind energy resources at the initiative of Uzbekgidroenergo JSC.

\subsection{The results and discussion}

To reduce the cost of the PVS, it is necessary to draw up a schedule of changes in the load per day, i.e. the dependence of the total load capacity of consumers working at the current time on the time during the day. At the same time, it is necessary to exclude simultaneous operation of high-power consumers or a large number of low-power consumers and distribute the connection of loads over time so that the output power of the power plant tends to a minimum [31-33]. For example, let's assume that the microwave oven is connected to the network only after the electric kettle is turned off (№ 1 and № 2, table 1). Moreover, to guarantee the serial connection of consumers and reduce the cost of PVS, their connection must be made to one AVI with one connection outlet.

When drawing up a schedule of load changes, it is not possible to accurately determine the intervals for switching on loads with a floating operating interval (see table 1). Therefore, when drawing up a schedule of load changes, we assume that such loads are permanently active for simplicity.

- taking into account the above circumstances, a schedule of load changes per day is drawn up in the form of a table (table 2). the Total load capacities at the selected time intervals are calculated using the formula

$$
P_{n, j}=\sum_{i=1}^{N} P_{\mathrm{oc}, i}
$$

Where, $\mathrm{N}$ is the number of consumers connected to the network on the $\mathrm{j}-$ th time interval. Schedule of load changes per day Table 2 . 
Table 2. Schedule of load changes per day

\begin{tabular}{|c|c|c|c|c|c|c|c|c|c|c|c|c|c|c|}
\hline \multirow[b]{2}{*}{$\begin{array}{l}5 \\
5 \\
01 \\
2\end{array}$} & \multirow[b]{2}{*}{ ర్జ } & \multicolumn{13}{|c|}{ Load capacity at time intervals, $\mathrm{W}$} \\
\hline & & $\begin{array}{l}8 \\
0 \\
0 \\
0 \\
0 \\
0\end{array}$ & $\begin{array}{l}0 \\
0 \\
0 \\
0 \\
0\end{array}$ & $\begin{array}{l}0 \\
\vdots \\
0 \\
0 \\
0\end{array}$ & 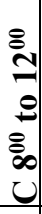 & 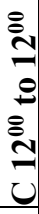 & 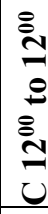 & 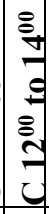 & 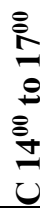 & 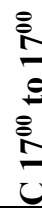 & $\frac{8}{1}$ & $\begin{array}{l}8 \\
0 \\
0 \\
0 \\
0 \\
1\end{array}$ & $\begin{array}{l}8 \\
0 \\
0 \\
0 \\
0 \\
0\end{array}$ & 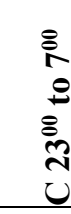 \\
\hline 1 & $\begin{array}{l}\text { Ele } \\
\text { ctri } \\
\mathrm{c}\end{array}$ & E & & & & & $\vec{N}$ & & & & 崩 & & & \\
\hline 2 & $\begin{array}{l}\text { Ket } \\
\text { tle }\end{array}$ & & $\frac{1}{8}$ & & & & & $\vec{g}$ & & & & प्रे & & \\
\hline 3 & $\begin{array}{l}\text { Mi } \\
\text { cro } \\
\text { wa } \\
\text { ve } \\
\text { ove } \\
\text { n }\end{array}$ & N & & $\stackrel{\omega}{N}$ & & $\frac{\omega}{u}$ & $\underset{\omega}{\omega}$ & $\stackrel{4}{a}$ & & & $\underset{\omega}{\omega}$ & & & $\frac{\omega}{N}$ \\
\hline 4 & $\begin{array}{l}\text { Ref } \\
\text { rige } \\
\text { rato } \\
\mathrm{r}\end{array}$ & & & & & & & & & & & & $\begin{array}{l}\infty \\
\infty \\
\text { in }\end{array}$ & \\
\hline 5 & $\begin{array}{l}\text { Tel } \\
\text { evi } \\
\text { sio } \\
n\end{array}$ & & & & & & & & & & & & 8 & \\
\hline 6 & $\begin{array}{l}\text { Lig } \\
\text { htin } \\
\mathrm{g} \text { of } \\
\text { holl }\end{array}$ & 少 & & & g & & & & & & & & & y \\
\hline 7 & $\begin{array}{l}\text { Lig } \\
\text { htin } \\
\mathrm{g} \text { of } \\
\text { dini } \\
\text { ng } \\
\text { roo } \\
\mathrm{m}\end{array}$ & & & ह & & & & Ua & & & & हl & & \\
\hline 8 & $\begin{array}{l}\text { Toi } \\
\text { let } \\
\text { and } \\
\text { oth } \\
\text { ers }\end{array}$ & & & & & & & & $\vec{N}$ & & & & & \\
\hline & $\overrightarrow{\stackrel{0}{0}}$ & 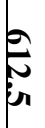 & 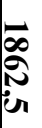 & ת & נِ & 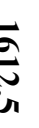 & 文 & $\prod_{\substack{n \\
n}}^{u}$ & N & 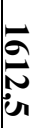 & గ゙ & $\begin{array}{l}n \\
\tilde{n} \\
\tilde{n}\end{array}$ & ஓे & $\underset{\text { N }}{\mathbf{N}}$ \\
\hline
\end{tabular}

- Such electrical appliances as a refrigerator, pumps, electric drill and a number of others, at the time of startup, consume power 5-6 times more than the "passport". If there are a lot of such consumers with high power, this can lead to an increase in output power and an increase in the cost of an Autonomous solar power plant. In this case, it is advisable to exclude the simultaneous inclusion of such electrical appliances and to consume the starting power from the batteries.
- during the daytime, the solar battery charges the battery and provides power to consumers. We accept for the day time interval: in summer $\Delta \mathrm{tdt}=14 \mathrm{~h}$ (from $6^{00}$ to $\left.20^{00}\right)$, in winter $\Delta \mathrm{tdt}=8 \mathrm{~h}$ (from $8^{00}$ to $\left.16^{00}\right)$. Then the output power of an Autonomous solar power plant is defined as the maximum load power for the summer daytime interval using the formula

$$
P_{H}=\max \left\{P_{H, j}\right\}, \forall j \in \overline{1, M}
$$

Where, $M$ is the number of selected time intervals included in the summer daylight time interval.

According to table. 2 the output power of an Autonomous solar power plant is $P_{\mathrm{H}}=1862.5 \mathrm{~W}$, which will be used to calculate the power of the solar battery of the PVS.

The above method of calculating the output power of the PVS takes into account the change in time of the load power value and is a General case. In a particular case, the load of the PVS does not change, i.e. it is constant. These consumers include cellular stations, operational power supply systems for electric power stations, traffic lights, etc. In this case, the output power of an Autonomous solar power plant must correspond to the total power of the loads.

Grid-connected Solar system.A rooftop solar photovoltaic system is basically a small power plant on your roof. The mesh interactive roof for Solar photovoltaics(PV) is mainly made up of basic components. These are solar photovoltaic modules, mounting structure for modules and inverter power conditioning units. Solar photovoltaic modules form an array, and this requires a mounting structure to hold the modules at the required angle for maximum generation. Solar panels convert solar energy in the form of light into electricity in the form of direct current (DC). Direct current electrical energy is converted to alternating current (AC) by an inverter in the power supply air conditioning unit, which is connected to the power grid via an $\mathrm{AC}$ distribution Board. The $\mathrm{AC}$ output power can be measured via the connected measuring panel. The 415 $\mathrm{V}$ AC output of the system can be synchronized with the grid, and electricity can be exported to the grid depending on solar power generation and local consumption.

Synchronization of the network. Electric inverters convert direct current generated by solar photovoltaic modules into alternating current. Therefore, the solar modules must be connected to the inverters. We currently have smart network interactive inverters. These inverters can produce variable power that corresponds to the voltage and frequency of the network and power line to which it is connected. There is another requirement to add an isolation transformer. For safety reasons, an isolation transformer is used to transfer electrical energy from the inverter to the connected load while isolating the load from the power source. In addition, direct current injection into the network can be avoided by using an isolation transformer at the output of the inverter. The energy generated by the rooftop Solar system during daytime can be fully utilized by powering construction loads and feeding excess energy to the grid for as long as it is available. Whenever solar power is 
unavailable due to a shadow or cloudy day, construction loads can be serviced by drawing power from the grid or DG sets. Smart inverters automatically understand the power situation and always prefer the energy generated by solar modules.

Selection of Autonomous PVS voltage inverters. When choosing an inverter, it is necessary to calculate the total load of the devices connected to the inverter and increase the received power by at least $30 \%$. The inverter selected for this power will allow you to run such electrical appliances as a compressor refrigerator, pumps, etc., with starting capacities 3-4 times higher than the passport one. In this case, an Autonomous voltage inverter consistently feeds an electric kettle and a microwave oven through a single outlet. Moreover, the power of a microwave oven is greater than the power of an electric kettle. Therefore, the power of the inverter is $1950 \mathrm{~W}$ and is determined by increasing the power of the microwave oven by $30 \%$, converted to the main bus.

If a feed rate is applied at the project location, then a separate feed counter (export counter) is appropriate. The feed rate meter registers the gross output from the Solar system on the roof. However, a conventional energy meter (imported meter) records the building's electricity consumption. Currently, the city of Tashkent has a tariff feed-in scheme, and therefore tariff feed-in counters are used here [34, 35]. However, in cases where the provision on a preferential tariff is not applicable, the project developer may have a network accounting system (bidirectional counter).

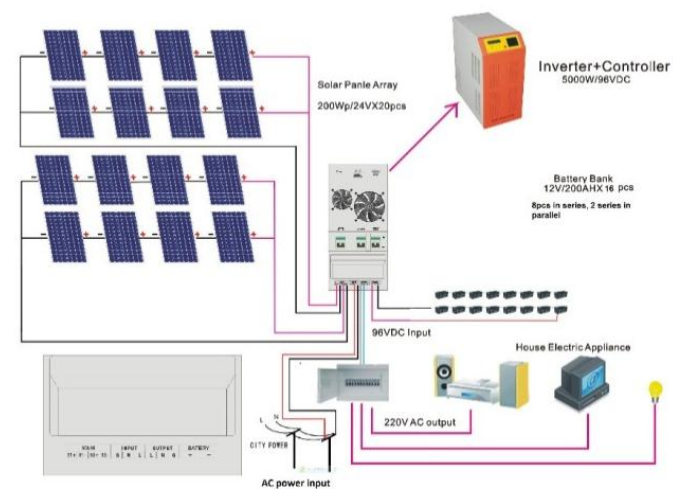

Fig. 2. The structure of the Autonomous photovoltaic stations, and dosing regimen submission.

Advantages of solar photovoltaic systems on the roof.1-ideally, networked interactive systems do not require battery backup, since the grid acts as a backup to supply excess solar power and vice-versa. So the cost of a network-connected system is approximately less.

The initial cost is reduced from $40 \%$ to $50 \%$, and the cost of battery maintenance is also reduced:

2 -the energy produced is fully used.

3-multiple batteries can be installed to ensure uninterrupted power supply in the event of a power failure.

4-a large amount of reduced invoice will be there if we use.

5-maintenance costs are negligible.

\section{Equations and mathematics}

Various installation options for solar energy projects. For successful and uninterrupted operation of roof and small solar power plants, various situations and conditions must be developed to make them a workable business model [36,37]. There are many possible business models, some of which can be considered by MNRE as follows:

a) solar installation seeded by consumer.

I) a rooftop solar installation owned, operated and maintained by the consumer.

II) a rooftop solar facility owned by the consumer but operated and maintained by a third party.

b) solar installations owned, operated and maintained by a third party.

A third party implements a solar installation and provides services to consumers. Excess electricity can be pumped into the power grid. Combinations can be:

I) device as a captive generating unit for roof owners:

The 3rd party implements the object on the roof or in the consumer's premises; the consumer can invest or not invest as equity in the object by mutual agreement between them. The 3rd party can also arrange for the operation and maintenance of the facility. Power was sold to the owner of the roof.

II) the solar lease model, sale to grid:

The 3rd party implementing the solar installation enters into a lease agreement with the consumer for a medium-and long-term lease basis. The object is fully owned by a third party, and the consumer is not required to make any investment in the object. The generated energy is fed to the grid, and the roof owner receives rent.

c) solar installations owned by public utilities;

d) a solar installation owned and maintained with a disk. DISCOM can own, operate and maintain a solar installation, and can also choose to subcontract operation and maintenance. DISCOM can refund the cost in the form of a suitable tariff. Power generation can also be used by DISCOM to meet its obligations to purchase solar renewable energy sources.

II) the distribution licensee provides appropriate viability gap funds.

Discom may designate a 3rd party to implement solar installations on its own behalf and provide the appropriate funds or viability gap funds to implement such an installation. It can also enter into an agreement with a third party that operates and maintains solar installations.

Scope and implementation: TSTUniversity has a great potential for network generation of solar energy using photovoltaic cells due to the following database.

1-the grid is available for almost 24 hours. Therefore, it is preferable to connect to the grid.

2-most of the domestic consumer has an inverter and a battery, so only the cost of the panel should be borne by the domestic user.

3-most official buildings have their own DG set, so there is no need for an emergency backup battery in case of a network failure on Sunny days. 
4-most residential buildings are single-story. In this way, a large unused roof area is available for power generation.

5-a Large unused roof area of official buildings and a flat area are also available.

Data and Facts:

1-the available roof area is from 100 sq. $\mathrm{m} . \mathrm{m}$ to 150 sq. $\mathrm{m}$ in part I and II, and the energy demand is 50006500 units per year and about 500 homes.

2-the available roof area is 50-100 square meters for plot III and IV, and the energy requirement is 1000-2000 units per year, and there are approximately 1,500 homes there.

3 -the available roof area is from 10,000 sq. m. m up to 15,000 sq. $\mathrm{m}$ in College buildings, the approximate energy requirement is 50,000 units per year.

4-a $1 \mathrm{~kW}$ photovoltaic panel requires an area of about 10 sq. m. 8 to. It will cost 9 .

5-the total average consumption of the University per year is $25 \times 106$ units.

6-one KWp can generate 1500 Units per year.

Calculation and analysis:

1-home conditions I and II:

- from the first data point, the average area available for home conditions I and II is 130 square meters

- If we only use 100 square meters of space for PV Generation then the maximum energy can be produced $=$ $100 / 10=10 \mathrm{kWh}$

* The average energy-generating year is $1500 \times 10=15,000$ units, while the energy demand for one alternating current is approximately 6000 units.

- It is clear from the calculation that energy can be produced twice as much as consumption.

* A minimum of $4 \mathrm{~kW}$ is sufficient to meet the demand of 6000 units

- Installation cost $0.8 \times 10=8$ euros $30 \%=5.6$ euros. A Bank loan is provided at no more than $10 \%$ per annum.

- If we invest this money,then over 20 years it can give about 5000 per month plus 2000 savings on the account, so the total benefit is 7000 per month (which is a good payback).

2-installation on the roof of college and office buildings:

- from the first data point, the average available area is 10,000 sq. m. metres'

- If we use only 5000 square meters of area for photovoltaic plants generation then the maximum energy can be produced $=5000 / 10=500 \mathrm{kWh}$

* Average energy production per year= $1500 \times 5000=7500000$ units, while the energy requirement for a college is about 500000 units.

- The calculation shows that at $50 \%$ of the roof area, 1.5 times more energy can be generated .

- Installation cost $=0.8 \times 500=40$ euros $90 \%$ subsidy $=4$ euros.

3-General requirements and potential of the University:

- from the University account, the average unit consumption per month is 20 Euro units, so per year the unit consumption is 24000000 units.

* Capacity requirement to meet total demand $=24000000 / 1500=16 \mathrm{MW}$.
* Purchased area $=160,000$ sq $\mathrm{m}$

- Where, as the roof area available at TSTU University is approximately 200,000 sq. $\mathrm{m}$.

Calculation of the power of solar panels PVS. Calculating the power of solar panels is necessary for their correct selection and providing the necessary amount of electricity to an Autonomous solar power plant. The required power of the solar battery is determined by the ratio

$$
P_{\text {сб }}=\frac{P_{\text {ош }}}{\eta_{1}}=\frac{P_{H}}{\eta_{1}}+P_{\text {зу }} / \eta_{1} \eta_{2}
$$

The amount of electricity generated by the solar panel depends on weather conditions. To take this factor into account, it is necessary to determine the amount of solar energy that can be counted on in a given area. This data can usually be obtained from a local solar supplier or a hydrometeorological station. It is important to take into account two factors: the average annual solar radiation, as well as its monthly average values under the worst weather conditions [38, 39].

Using the first factor, the photovoltaic system can be calculated in accordance with the average annual solar radiation, i.e. in some months there will be more energy than required, and in others - less. When choosing the second factor, there will always be at least enough energy to meet the needs, if you exclude extremely long periods of bad weather.

Now you can calculate the rated power of the photovoltaic module. Taking the value of solar radiation for the period of interest from the tables and dividing it by 1000 , we get the so-called number of peak hours, i.e. the conditional time during which the sun shines with an intensity of $1000 \mathrm{~W} / \mathrm{m}^{2}$. The $P w$ module will generate the following amount of energy during the Selected period:

$$
W=k E P w / 1000,
$$

Where, $\mathrm{E}$ is the insolation value for the selected period; $\mathrm{k}$ is the coefficient equal to 0.5 and 0.7 in summer and winter, respectively. It makes a correction for the loss of power of solar cells when heated in the sun, and also takes into account the oblique fall of rays on the surface of the modules during the day. The difference in its value in winter and summer is due to less heating of the elements in winter [40-43].

Based on the total power of the energy consumed and the above formula, it is easy to calculate the total power of the modules, by simply dividing it by the power of one module, we get the number of modules.

Using photovoltaic modules of different capacities, it is possible to build a solar battery with the required installed capacity. In this case, there are two possible options: either insufficient or excessive power of solar panels. In the first case, the solar battery will not be able to meet the overall energy demand. In the second case, you will have an excess of electricity [44-45].

$$
\eta=\frac{P_{\mathrm{H}}}{P_{\text {сб }}}=\frac{P_{H} \eta_{1} \eta_{2}}{P_{H} \eta_{2}+P_{\text {зу }}}
$$

Calculation of PVS efficiency Evaluation of the efficiency of an Autonomous solar power plant is 
determined by the efficiency coefficient. The efficiency of the PVS is determined by the ratio, where $\eta_{1}$-is the efficiency of a DC pulse converter of a step - down type.

\section{Conclusions}

From the above calculations, it is clear that the University has a maximum solar photovoltaic generation capacity of $32 \mathrm{MW}$, and the need is $16 \mathrm{MW}$, so an approximate 2000000 units per month can be fed to the grid, and the total benefit will be about 50 euros per month. Since the solar panel has a lifetime of about 25 years and approximately zero maintenance costs for the connected system, this scheme is very useful because it reduces carbon consumption, and by using this scheme, we can reduce the effect of global warming.

1.developed a method 1 for calculating the capacity of Autonomous solar power plants and its elements, which allows you to take into account the change in load during the day.

2. Taking into account changes in the load schedule during the night time interval allows you to accurately determine the required battery capacity.

3. The expression for determining the required battery capacity of an Autonomous solar power plant can be easily generalized for any number of changes in the load schedule steps.

4. the developed method for calculating the capacity of Autonomous solar power plants allows us to exclude unjustified overestimation of the capacity of power plant elements and increase the cost of an Autonomous solar power plant.

Thanks to Academician M.K.Bahadirkhanov and Professor N.F.Zikrillayev for discussing the results and valuable advice.

\section{References}

1. G. P. Okhotkin. Methods for calculating the capacity of solar power plants. Bulletin of the Chuvash University. No. 3, article 222-230, 2013.

2. Uttarakhand Renewable Energy development Agency, Government of Uttarakhand, Uttarakhand Rooftop Solar Photovoltaic Power Plant Policy, 2013 and amendments 2014-15.

3. Uttar Pradesh Electricity Regulatory Commission, Rooftop Solar PV Grid Interactive Systems Gross / Net Metering Regulations, 2015.

4. Government of India Ministry of New \& Renewable Energy Off-Grid and Decentralized Solar Application Scheme: Operational Guidelines for Grid Connected Rooftop and Small Solar Power, 26th June, 2014.

5. SouvikGangu, SunandaSinha, Estimation of annual energy generation from a small grid connected solar photovoltaic power plant in patiala, journal of engineering research and studies, vol. issue ii/apriljune, pp. 43-44, 2011.

6. G.Ravi Kumar, A.Hari Prasad, N.SatyaSaketha, K.Saichandana,A New Innovative Design principle of Grid Interactive Roof Top Solar Photovoltaic
Power Generation, IJEAR Vol. 4, Issue Spl-1, Jan June 2014.

7. Aronova E. S., okhotkin G. P., Terukov E. I., Shvartz M. Z. Features of the operation of thin-film solar modules based on silicon as part of a power plant at the latitude of Cheboksary // Dynamics of nonlinear discrete electrical and electronic systems: materials IX all-Russian. scientific and technical Conf. Cheboksary: Chuvash publishing house.University press, 2011. S. 222-224.

8. Okhotkin G. P., Serebryannikov A.V. basic principles of building Autonomous solar power plants [Electronic resource] // Modern problems of science and education, 2012.

9. Finlay Colville. How Buried Contacts Brought Lasers to Life in Solar/ Production\&inspection productiontechnology USA, pp. 74-77, 2009.

10. Chen Jiahe, Emanuele Cornagliotti, Eddy Simoen, Ellen Hieckmann, Joerg Weber and Jef Poortmans, "Adeeplevel transient spectroscopy study on the in terfacestates across grain boundaries in multicrystalline silicon" physica status solidi (RRL)Rapid Research Letters 5, no. 8 (2011): 277-279.

11. M.K.Bakhadyrkhanov, S.A.Valiev, N.F.Zikrillaev, S.V.Koveshnikov, E.B.Saitov, S.A.Tachilin. Silicon photovoltaic cells with clusters of nickel atoms. Applied solar energy 52 (4), pp.278-281, 2016.

12. Sh.A.Faiziev and Yu.B.Sobirov. Measurements of Solar Resources in Uzbekistan // Applied Solar Energy, 2017, Vol. 53, No. 1, pp. 57-60.

13. Javoxir Toshov., Elyor Saitov. Portable autonomous solar power plant for individual use. E3S Web of Conferences 139 01087. 2019.

14. Shavkat Fayziev, Yuldash Sobirov, Sirojiddin Makhmudov. Measurement of the Direct Flux of Solar Radiation During Operation of a Big Solar Furnace // International Journal of Sustainable and Green Energy 2018; 7(4): 21-28 http://www.sciencepublishinggroup.com/j/ijsge doi: 10.11648/ j.ijrse.20180704.11

15. I.Sapaev, E.Saitov, N.Zoxidov and B.Kamanov. Matlab-model of a solar photovoltaic station integrated with a local electrical network. Conmechydro - 2020 IOP Conf. Series: Materials Science and Engineering 883(2020) 012116.

16. Krivtsov V. S., Oleynikov a.m. et al. Inexhaustible energy. Book 1. Wind Power Generators// Textbook. Kharkiv: NATs.Aerocom. UN.-t "Kharkiv aviation. Inst.", Sevastopol: Sevast. NATs. tehn. Univ., 2003. $400 \mathrm{p}$.

17. Krivtsov V. S., Oleynikov a.m. et al. Inexhaustible energy. KN.2. Wind power// Textbook. Kharkiv: NATs.Aerocom. UN.-t "Kharkiv aviation. Inst.", Sevastopol: Sevast. NATs. tehn. Univ., 2004. -519 p.

18. Derzky V. G. Analytical forecast of world wind power development /Derzky V. G. //Power engineering and electrification-2010. - no. 1. - P. 5356.

19. Tadzhiev U. A., Kiseleva E. I., tadzhiev M. U., Zahidov R. A. Features of formation of wind flows over the territory of Uzbekistan and the possibility of 
their use for power generation. Part I.// Solar Energy Equipment. 2014. No. 3. S. 46-52.

20. Community R. A., Kremkow V. M. the wind energy Potential of Uzbekistan// Solar technology. 2015. no. 4. Pp. 106-107.

21. Community R. A., Kremkow V. M. the wind energy Potential of Uzbekistan// Solar technology. 2015. no. 4. Pp. 106-107.

22. Zavarina M. V. Calculated wind speeds at the heights of the lower layer of the atmosphere. - L.: Hydrometeoizdat, 1971. - $162 \mathrm{p}$.

23. Shoguchkarov S.Q., Jamolov T.R., Mukhtarov N.Y., Yuldoshev I.A. Study of the Operating Parameters of a Wind Power Plant with 0,75 MW Power under the Conditions of Tashkent Oblast Applied Solar Energy.2018. Vol.54, pp. 392-394.

24. M.K.Bakhadyrkhanov., S.A.Valiev., N.F.Zikrillaev., S.V.Koveshnikov., E.B.Saitov., S.A.Tachilin. Silicon-based solar cells with clusters of nickel atoms // Geliotekhnika No. 4 pp. 28-32, 2016.

25. М.К.Бахадырханов.,

С.А.Валиев., Н.Ф.Зикриллаев., С.В.Ковешников., Э.Б.Саитов., С.А.Тачилин. Фотоэлементы на основе кремния с кластерами атомов никеля. // Гелиотехника №4 2016 г. Стр.28-32.

26. E.B.Saitov. Study of Quantitative and Qualitative Characteristics of Nickel Clusters and Semiconductor Structures. Journal of Materials Science and Chemical Engineering. №4 y. 2016, pp. 30-35.

27. Abdurakhmanov B.A., Bakhadirkhanov M.K., Ayupov K.S., Iliyev H.M., Mavlyanov A., Saitov E.B., Kamalov H.U. Formation of Clusters of Impurity Atoms of Nickel in Silicon and Controlling Their Parameters. Nanoscience and Nanotechnology, Vol. 4, No. 2, 2014. pp. 23-26.

28. Зикриллаев Н.Ф., Саитов Э.Б. Фотоэлементы на основе кремния с микробарьерами Шоттки. Вестник Туринского политехнического университет; 2014. С. 31-33.

29. Саитов Э.Б. Исследование кремниевых фотоэлементов с Si-Ge микрогетероструктурами. Спец выпуск //Вестник ТашГТУ, 2015.С.66-71.

30.Илиев Х.М., Саитов Э.Б., Сайдалиев С.Х., Тачилин С.А. Переносная автономная солнечная электростанция индивидуального использования. Проблемы энерго- и ресурсосбережения. ТашГТУ, 2014, №1-2. с. 183-185.

31. Зикриллаев Н.Ф, Саитов Э.Б., Тухтасинов М.М. Низкотемпературная диффузия примесей $\mathrm{Ge}, \mathrm{S}$, $\mathrm{Ni}$ и $\mathrm{Mn}$ в кремнии для получения фотоэлементов. Вестник Туринского политехнического университета, 2014. с. 34-39.

32. Зикриллаев Н.Ф., Саитов Э.Б., Тачилин С.А. Эффективные инверторы для альтернативных источников энергии. Международная научнопрактическая конференция «Проблемы современного машиностроения». Андижан 16-17 мая 2013 года. С.16-18.

33. Бахадырханов М.К. Абдурахмонов Б.А, Саитов Э.Б. Исследование вольт-амперной характеристики микроструктуры кластеров атомов никель-кремний. Академия наук
Республики Узбекистан. Фундаментальное и прикладной вопроси физики. Труди международный конференции посвященной 70летю физика техника институт НПО «Физикасонца»:. 14 - 15 ноября 2013 г. Ташкент, с. 107108.

34. M.K.Bakhadyrkhanov, S.A.Valiev, N.F.Zikrillaev, S.V.Koveshnikov, E.B.Saitov., S. A.Tachilin. Silicon Photovoltaic Cells with Clusters of Nickel Atoms. Applied Solar Energy, 2016, Vol. 52, No. 4, pp. 278 281.

35. B.A.Abdurakhmanov, M.K.Bakhadirkhanov, H.M.Iliyev, S.B.Isamov, A.Mavlyanov, E.B.Saitov, H.U.Kamalov, Z.Saparniyazova, O.Sattarov, U.Kh.Sodikov, N.F.Zikrillayev. Silicon with Clusters of Impurity Atoms as a Novel Material for Photovoltaics. Nanoscience and Nanotechnology 2014, 4(3): 41-43.

36. М.К.Бахадирханов, С.А.Валиев, Н.Ф.Зикриллаев, С.В.Ковешников, Э.Б.Саитов, С.А.Тачилин. Фотоэлементы на основе кремния с кластерами атомов никеля. Журнал Гелиотехника, Академия наук республика Узбекистан, №4, 28-32 ст.

37. Javoxir Toshov., Elyor Saitov. Portable autonomous solar power plant for individual use. E3S Web of Conferences 139 01087. 2019.

38. E.B.Saitov. Technology of manufacturing solar cells with clusters of $\mathrm{Ni}$ atoms. Asian journal of multidimensional research impact factor, ISSN: 2278-4853 Vol 8, Issue 3, March $2019=6.053$, pp. 494-499.

39. Zikrillayev Nurilla, Saitov Elyor, Botirov Bozorbek, Nasirdinov Bakhodirw, Kurbanov Yunus, Turayev Farxodjon, Shodiyeva Nozina. Study of the results of diffusion doping technique for producing heterostructures (Si-Ge) using microprobe analysis. Austrian Journal of Technical and Natural Sciences. «East West» Association for Advanced Studies and Higher Education GmbH. No.1-2. pp.56-61, 2019.

40. I.Sapaev, E.Saitov, N.Zoxidov and B.Kamanov. Matlab-model of a solar photovoltaic station integrated with a local electrical network. Conmechydro - 2020 IOP Conf. Series: Materials Science and Engineering 883(2020) 012116.

41. Saitov E.B, Toshov J.B, Umarov Sh.B., Fayzullayev B.H., Abdullabekov I.A, NasriddinovB.A. Optimization of Solar Power Systems in Different Regions. Journal of critical reviews, ISSN - 23945125VOL 7, ISSUE 15, 2020.

42. Saitov Elyor Bakhriddinovich, Pulatov Abror Obidovich. Development of an Experiment Control System at a Laboratory Installation of a Photovoltaic Station in a Remote access Mode Based on Web Technologies. Journal of critical reviews, ISSN 2394-5125 VOL 7, ISSUE 15, 2020.

43. Zikrillayev Nurullo, Saitov Elyor. Silicon materials the future of photovoltaics. Monograph - LAP LAMBERT Academic Publishing. 2019, ISBN: $987-$ 620-0-50311-4.

44. Javoxir Toshov., Elyor Saitov. Portable autonomous solar power plant for individual use. E3S Web of Conferences 139 01087. 2019. 
45. I Sapaev, E Saitov, N Zoxidov, B Kamanov. Matlabmodel of a solar photovoltaic station integrated with a local electrical network. IOP Conference Series: Materials Science and Engineering, 883, 1, 012116 , IOP Publishing, 2020/7/1. 